\title{
DisTRIBUTION AND SigNIFICANCE OF MESOZOIC VERTEBRATE TRACE FOSSILS IN DINOSAUR NATIONAL MONUMENT
}

\author{
MARTIN LOCKLEY $\bullet$ KELLY CONRAD $\bullet$ MARC PAQUETTE \\ GEOLOGY DEPARTMENT $\downarrow$ UNIVERSITY OF COLORADO \\ DENVER
}

\section{$\checkmark \quad$ INTRODUCTION}

Dinosaur National Monument (DNM) encompasses a large area with surface exposures of Mesozoic rocks. Although only one isolated footprint (from an unknown locality) had previously been discovered at DNM, there is a high potential for preservation of fossil footprints in this area, as has been proven by discoveries in similar rocks in the region around DNM, and during research activity at DNM. As reported by Lockley et al. (1990), the purpose of this research is to seek, document and interpret vertebrate trace fossils in any of the ten potentially track-bearing Mesozoic stratigraphic units in which footprints might be discovered.

During the course of the first year (6/90-6/91) the University of Colorado at Denver Research Group documented 11 localities where tracks were discovered at one or more stratigraphic levels (Lockley et al. 1990, 1991). In the first part of the second year of investigation (7/91-10/91) the research group discovered an additional five localities, and three additional sites were reported to us by Park Paleontologists and other researchers. This brings the total to 19 localities, of which three include at least two levels with tracks (Total $=22$ localities). As discussed below, the tracks provide evidence of the activities of several dozen animals that represent distinct ancient animal communities.

\section{$\checkmark \quad$ FIELD METHODS}

During the summer of 1991 (end of year one and start of year two), reconaissance exploration for vertebrate tracks at DNM was undertaken by Martin Lockley, Kelly Conrad and Mark Paquette in June, July and August. Following our initial success with tracksite discovery in the late Triassic Chinle/Popo Agie beds of the western part of DNM, we continued to survey this unit throughout DNM. Tracks were found at all but the last locality. At all sites where exposure permitted, we also measured the stratigraphic position of trackbearing layers.

We also began a collecting and replicating program that resulted in the acquisition of 27 original specimens and replicas. Tracks were molded from original specimens in the field using latex rubber, then replicated in the lab using plaster of Paris.

\section{- RESUlts}

During the course of this study, it has become apparent that there is some confusion about stratigraphic nomenclature in the study area (Uintah County, Utah and Moffat County, Colorado). The Late Triassic red bed sequence, referred to as the Chinle Formation in many areas and at DNM (e.g. Rowley at al. 1979), is referred to, at least in part, as 
the Popo Agie Formation in Wyoming (High and Picard, 1969; Stewart and others, 1972; Pipiringos and O'Sullivan, 1978). Spencer Lucas (written communication 1991) suggests that at DNM the lower part of the sequence, the conglomeratic Gartra Member and the overlying yellowish Ochre Member both belong to the Popo Agie and are separated by an unconformity from the younger, upper Red Siltstone member (sensu Pipiringos and O'Sullivan 1978) which consists of whitish and pink, ripple-marked sandstones alternating with brick red and purple siltstones and shales. These upper beds (about 20 to 25 meters) contain the track-bearing levels, and are equivalent to the Rock Point Member of the Chinle Formation. Thus the red bed sequence essentially consists of two units and we therefore use the compound term Popo Agi/Chinle Formation to refer to this entire red bed sequence (Lockley et al. 1990, 1991).

Uncertainty also exists regarding the age and nomenclature of units in the Glen Canyon Sandstone, overlying the Popo Agie/Chinle sequence at DNM. However the discovery of Late Triassic tracks (Brachychirotherium) in beds seven meters above the base of this unit (UCD loc. 8) clarify the situation considerable. They indicate the existence of an older, Wingate- equivalent, facies underlying the so called Navajo-Nugget beds that make up the majority of the group. This discovery provides biostratigraphic support for the stratigraphic conclusions of Poole and Stewart (1964a, p. D 38; 1964 b, p. 102), who inferred the existence of an older Wingate-equivalent unit in this area.

Studies of the Popo Agie/Chinle Formation, and the lower part of the Glen Canyon Group (Wingate equivalent) at DNM have revealed remarkable diverse Late Triassic vertebrate track assemblages. To date we have discovered 16 tracksites within the DNM boundaries - 14 in the Popo Agie/Chinle and two in the Glen Canyon Group, (see Lockley et al. 1990, 1991). The smallest of these sites has yielded only one or two isolated tracks whereas the larger sites reveal several dozen tracks comprising trackways of several animals. The trackways indicate the presence of at least seven different vertebrate (reptile) groups (Figure 1 and Table 1).

Assessment of the relative abundance of these animals, based on proportions of different trackway types, allows us to make a census of the compossition of the animal community represented by these tracks
Table 1. Vertebrate tracks from the Late Triassic, Dinosaur National Monument.

Dinosaur tracks (Agialopus and ?Grallator) Sphenodontid/lizard tracks (Rhynchosauroides) Tanysropheiid tracks (Gwyneddichnium)

Phytosaur tracks (?Chirotherium sp)

Aetosaur tracks (Brachychirotheium)

Synapsid tracks ( - no name -- )

?trilophosaur tracks (Apatopus)

(see Figure 2). This data suggests that the animal communities in this region were dominated by small bipedal dinosaurs (Agialopus) with tanystropheids (Gwyneddichnium) also being equally common. Phytosaurs and sphenodontids may also have been quite common (cf. Stewart and others 1972, for reports of phytosaur teeth). The DNM track assemblages compare favorably with those reported from the Late Triassic elsewhere in the western USA; for example from the Sloan Canyon Formation of New Mexico (Conrad and others, 1987), and from the Chinle Formation of eastern Utah (Lockley 1986).

One of the most interesting discoveries is that of two well preserved trackway segments which show evidence of the Gwyneddichnium trackmaker engaged in swimming activity. Instead of progressing on all fours with alternating steps of hind and front feet, the "swimming" trackways show only hind foot impressions situated in paired or side-by-side arrangement reminiscent of a hopping gait (except for the wider spacing between left and right footprints: see Figure 3, and discussion by Thulborn 1989). The tracks also show a very wide splay between the digit imprints and clear impressions of interdigital webbing between toes one and three. These features indicate a partially bouyant aquatic animal using the substrate to gain purchase in propelling itself forward with synchronous strokes of its hind feet. As shown by trackway speciment DINO 15006 the animal was evidently accelerating or at least increasing the length of strokes as it progressed. All other known Gwyneddichnium occurrences at DNM reveal widely splayed digit impressions and isolated tracks evidently indicative of swimming or bouyant activity. By contrast all occurrences of Gwyneddichnium trackways outside DNM reveal evidence of animals 


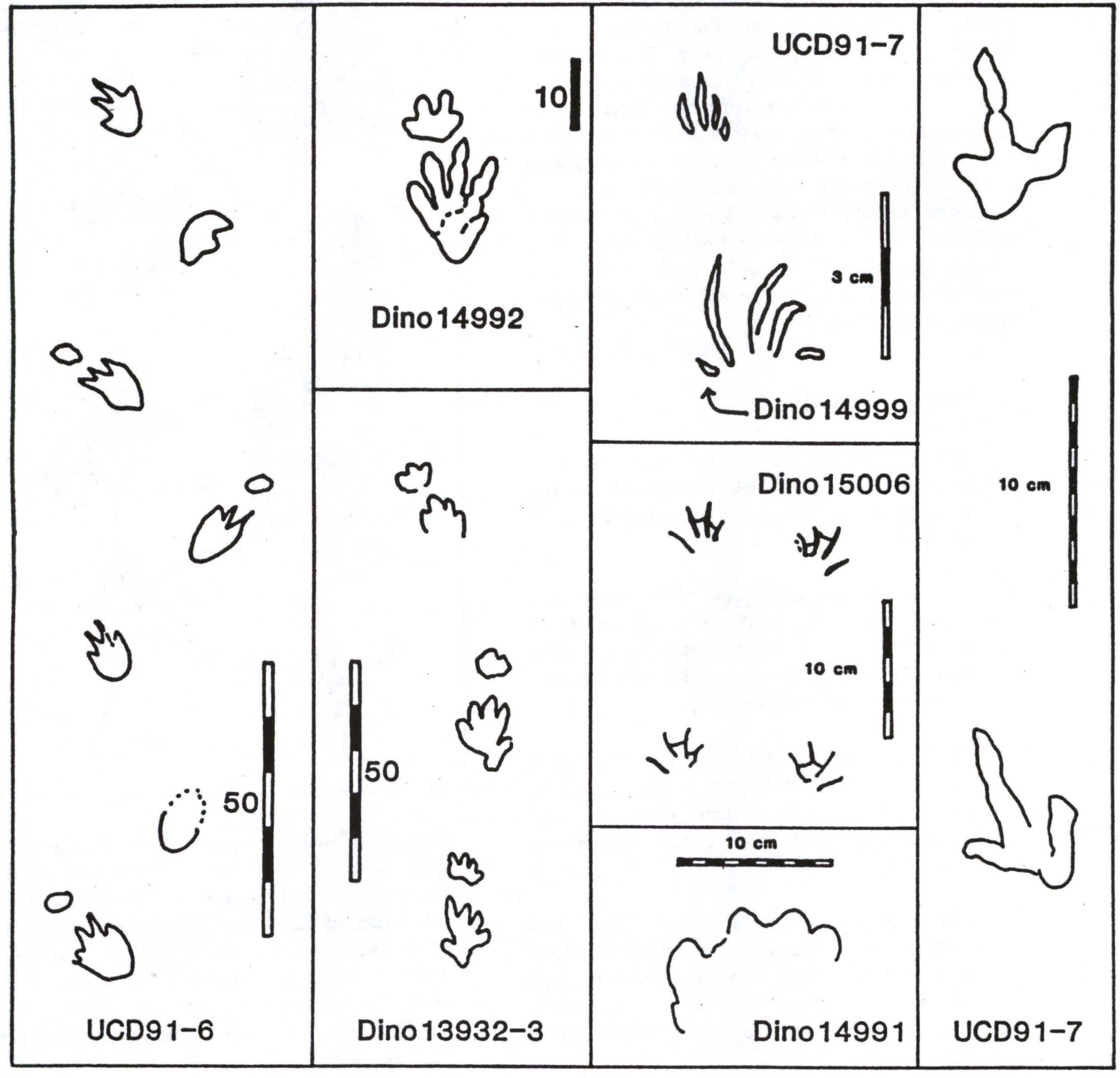

Figure 1. Summary of all known Late Triassic vertebrate track types from the Popo Agie Formation at Dinosaur National Monument (except for Apatopus). UCD91-6 = Phytosaur trackway, Dino 13932-3 and $14992=$ Brachychirotherium, Dino 1499 and UCD91-7 = Rhynchosauroides, Dino 15006 = Gwyneddichnium, Dino 14991 = ?synapsid track, and UCD91-7 = Agialopus (trackway of a small bipedal dinosaur). 
that were walking on all fours with digits held close together and directed forward in the direction of progression.

Gwyneddichnium is one of the few track types that have been attributed with some confidence to a particular genus. In this case, according to Baird (1986) and Lockley (1986) the trackmaker was probably the small aquatic reptile Tanytrachelos, which is known from skeletal remains in the Late Triassic of eastern and western North America. To the best of our knowledge this is the first example of an ichnogenus for which such well-preserved walking and swimming trackways are documented. Certainly it is the only example for a trackmaker identified with confidence down to the genus level. Moreover it is the only example we know of in which tracks can be used to demonstrate the exact configuration of interdigital webbing.

\section{$\checkmark \quad$ CONCLUSIONS}

1. The Late Triassic Ichnofaunas of the Dinosaur National Monument area indicate the former existence of diverse reptile-dominated faunas in this area.

2. The Ichnofaunas are typical of this epoch and compare favorably, in diversity and quality of preservation, with coeval track assemblages from the Chinle Formation and Dockum Group elsewhere in the western USA.

3. The high density of tracksites in a small area and at several stratigraphic levels suggests a good potential for further discovery and paleoecological and biostratigraphical synthesis in the future.

4. Well-preserved Gwyneddichnium tracks and trackways provide new insights into the anatomy of soft parts (foot web configuration) and behavior (swimming style) of the trackmaker, now thought to be the tanystropheid Tanytrachelos.

5. The occurrence of Late Triassic tracks in the basal part of the Glen Canyon Group provides important age constraints for a unit that was not previously dated with any certainty.

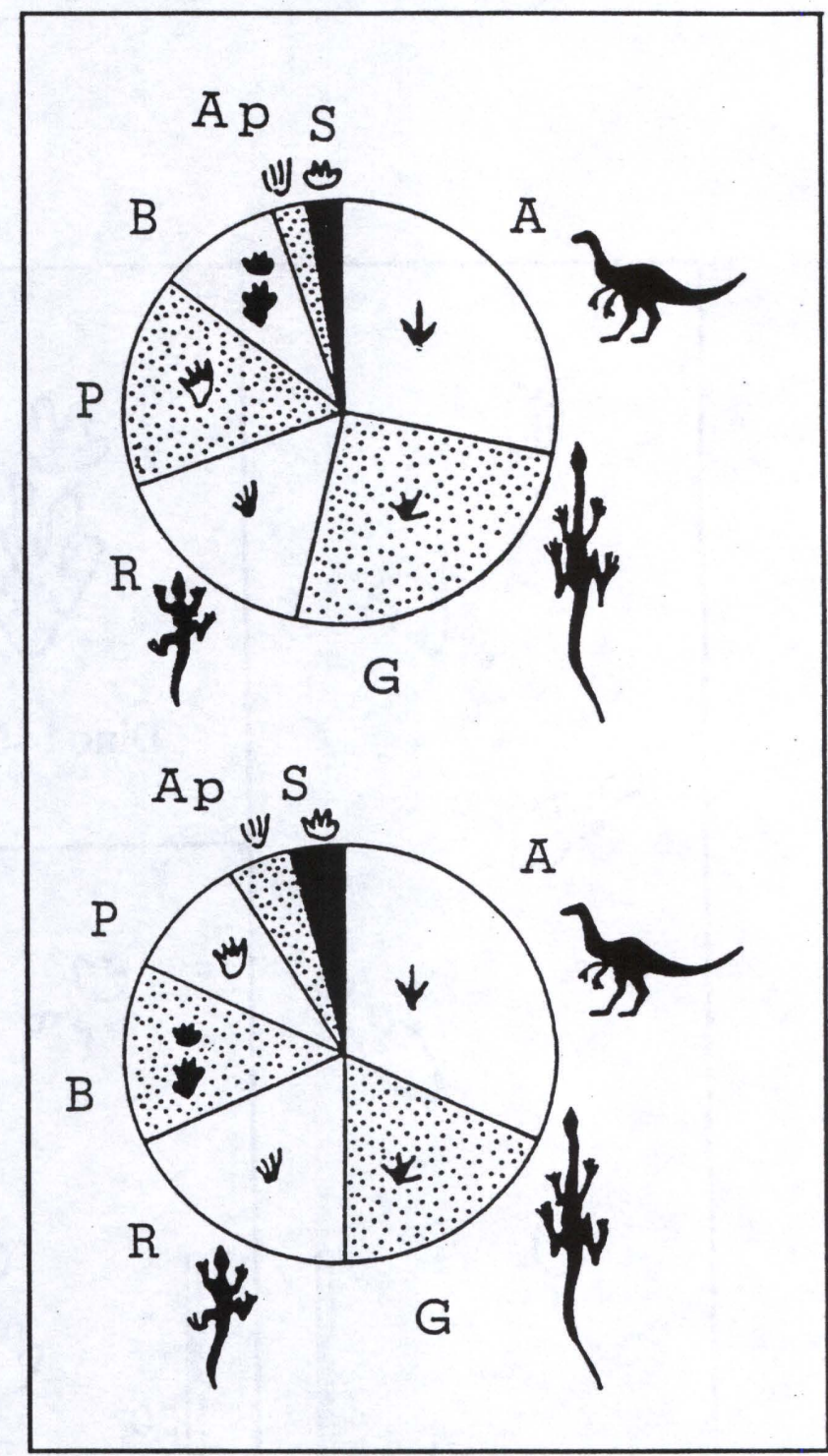

Fig. 2. Pie diagram proportions of different track types found in the Popo Agie/Chinle Formation at Dinosaur National Monument, arranged clockwise in rank order of abundance. Top diagram is based on total trackways (=individuals) $\mathbf{N}=32$, bottom diagram based on number of localities where a particular trackway type occurs, $\mathrm{N}=22$. Note similarity in proportions. The three most common track types are accompanied by a symbol showing the inferred trackmaker. $\mathrm{A}=$ Agialopus a bipedal theropod, $\mathbf{G}=$ Gwyneddichnium a tanystropheid, $\mathrm{R}=$ Rhynchosauroides a sphenodontid /lizard, B= Brachychirotherium probably an aetosaur, $\mathrm{P}=\mathrm{a}$ phytosaur, Ap = Apatopus, possibly a trilophosaur, and $S=$ synapsid (mammal-like reptile). 


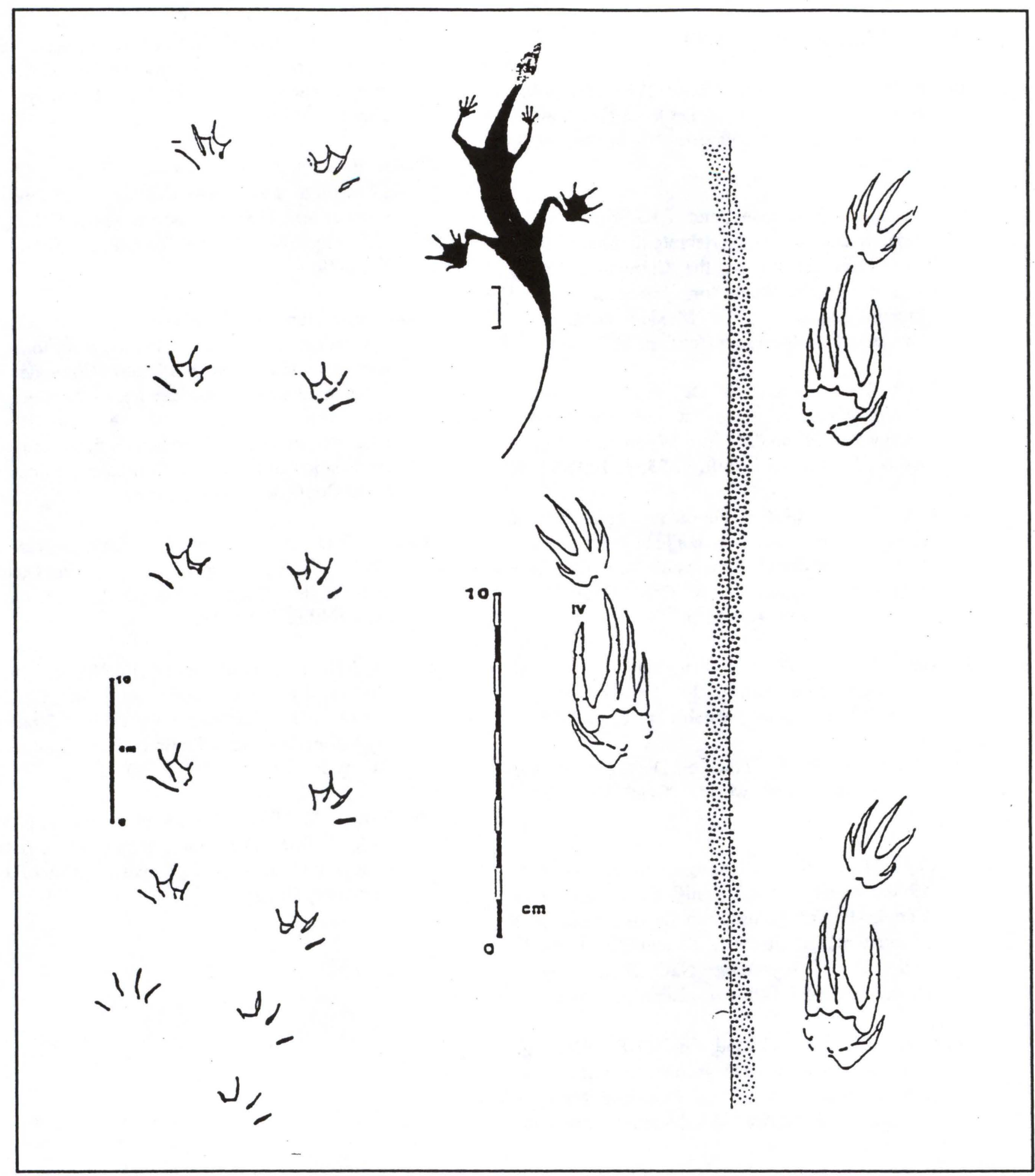

Fig. 3. Comparison of Gwyneddichnium trackway indicative of swimming behai $=$ vior $(l e f t=D I N O 50006)$ and walking (right - USGS specimen from Popo Agie Fm. Vermillion Creek, Moffat Co. Colorado). Trackmaker was probably Tanytrachelos (see silhouette of $20-25 \mathrm{~cm}$ long animal for general morphology, and text for details). 


\section{LITERATURE CITED}

Baird, D. 1986. Some Upper Triassic reptiles, footprints, and an amphibian from New Jersey. The Mosasaur: Jl. Delaware Paleont Soc. v. 3, p. 125-153.

Conrad, K., M.G. Lockley, and N.K. Prince. 1987. Triassic and Jurassic vertebrate dominated trace fossil assemblages of the Cimmaron Valley region: implications for paleoecology and biostratigraphy. New Mexico Geol. Soc. Guidebook. 38th Field Conf. p. 127-138.

High, L.R. Jr., and M.D. Picard. 1969. Stratigraphic relations within the upper Chugwater Group (Triassic, Wyoming). Amer. Assoc. Petrol. Geol. Bull. v. 53, p. 1091-1104.

Lockley, M.G. 1986. Dinosaaur Tracksites: a fieldguide published in conjunction with the First International Symposium on Dinosaur Tracks and Traces. Univ. Colo. Geol. Dept. Mag. Spec. Issue \#1. 56 p.

Lockley, M.G. 1990. Tracking the rise of Dinosaurs in Eastern Utah. Canyon Legacy. (Dan O'Laurie Mus., Moab). v. 2, p. 2-8.

Lockley, M.G. 1991. Tracking Dinosaurs: a new look at an ancient world. Cambridge Univ. Press. $240 \mathrm{p}$.

Lockley, M.G., R.F. Fleming, and K. Conrad. 1990. Distribution and significance of Mesozoic Vertebrate Trace Fossils in Dinosaur National Monument, In: Boyce M.S. and Plumb, G.E. (eds) Univ. Wyoming Nat. Park Service Research Center 14th Ann. Rept. p. 39-41.

Lockley, M.G., K. Conrad, and R.F. Fleming. 1991. Distribution and significance of Mesozoic vertebrate trace fossils in Dinosaur National Monument. First Annual Research Report (June 1991).
Pipiringos, G.N., and R.B. O'Sullivan. 1978. Principal Unconformities in Triassic and Jurassic rocks, Western Interior United StatesA Preliminary Survey. U.S. Geol Durvey Prof. Paper 1035-A, 29 p.

Poole, F.G., and J.H. Stewart. 1964a. Chinle Formation and Glen Canyon Sandstone in northeastern Utah and northwestern Colorado. U.S. Geological Survey Prof. Paper 501-D, p. D 30-39.

Poole, F.G., and J.H. Stewart. 1964b. Chinle Formation and Glen Canyon Sandstone in northeast Utah and northwest Colorado In: Sabatka, E.F. (ed.) Guidebook to the Geology and Mineral resources of the Uinta Basin, Utah's Hydrocarbon Storehouse. Intermountain Association of Petroleum Geologists, 13th Ann. Field Conf. Sept 16-19, 1964.

Rowley, P.D., D.M. Kinney, and W.R. Hansen. 1979. Geologic map of the Dinosaur Quarry Quadrangle, Uintah County, Utah. U.S. Geol. Survey Map GQ-1513.

Stewart, J.H., F.G. Poole, and R.F. Wilson. 1972. Stratigraphy and origin of the Chniley Formation and related Upper Triassic Strata in the Colorado Plateau Region. U.S. Geological Survey Professional Paper 690. $336 \mathrm{p}$.

Thulborn, R.A. 1989. The gais of dinosaurs, p. 3950 In: Gillette, D.D. and Lockley, M.G. (eds.) Dinosaur Tracks and Traces. Cambridge University Press, 454 pp. 